\title{
Crimes Against Life in the Criminal Legislation of the Russian Federation and Some Foreign States
}

\author{
Natalya V. Ivantsova \\ Interregional Open Social Institute, Yoshkar-Ola, Russia \\ Email: ivantzova.natalia@yandex.ru \\ Larisa V. Gorbunova \\ Mari State University, Yoshkar-Ola, Russia \\ Email: law@marsu.ru
}

\section{Doi:10.5901/mjss.2015.v6n3s7p187}

\begin{abstract}
In this article we are talking about legislative experience of foreign countries in the sphere of protection of individuals from violent crime. The definition of a public threat of violence under which the author understands wrongful, intentional, physical and / or mental abuse, violate constitutional right to physical and mental integrity of the individual and directed at another person (people) against or in addition to its (their) will, causing it significant harm or created a risk of causing such harm. Violent crime in the criminal laws of the Russian Federation and some other States are distributed on the various chapters and sections, based on the characteristics of a generic object. The article discussed in detail the offence of murder. A comparative analysis of its characteristics in the criminal code of the Russian Federation and a number of zarubezhnykh States. The study showed that a number of provisions of foreign law relating to criminal liability for murder, should be devoted to improving the rules in the criminal code. In particular, it is proposed to include in the number of aggravating the responsibility for the murder, causing death of their parents, spouse or child. The conclusion is made about the benefits of establishing in the law an exhaustive list of the circumstances aggravating a particular type of crime.
\end{abstract}

Keywords: criminal code, public violence threat, murder, violent crime, aggravating circumstances

\section{Introduction}

The appeal to the legislative experience of foreign countries is necessary for the purpose of a ratio of domestic legal system with legal systems of other states. (Ivantsova, 2004). Comparing the criminal legislation of various states, we are looking for its comparable properties to which number it is necessary to carry limits of criminal and legal regulation of the relations in the concrete sphere, its definiteness, severity and justice. Certainly, it is necessary to borrow reasonably the positive experience of criminal law-making and right application, considering national features, own experience of the state construction which is inseparable from the processes of law-making and right application.

The history of the mankind's existence abounds with examples of violent infringement of life and human health, their physical and sincere integrity. These crimes are «a crime core», the most stable part of all peoples; they characterize the state and dynamics of crime better, than all other crimes together taken. Physical and mental abuse, merging in the general flow of negative information and energy, destroys measured life of citizens. In the conditions of modern reality when, on the one hand, there is a strengthening of the Russian statehood, and on the other hand contact of Russia with the world problems of globalization, generating terrorism, extremism, taking of hostages, human trafficking, use of a slave labor and other violent acts in considerable scales takes place interest in the problems of reflection and estimates of an assessment of socially dangerous violence, which is not less than a third of the norms containing in criminal laws of both the Russian Federation, and the foreign states.

\section{Methods and Materials}

In legal literature, violence is defined in many ways. The variety of definitions of the criminal offense of violence is due, primarily, the lack of a legal interpretation of the term in the legislation. We have proposed the following definition. Socially dangerous violence is wrongful, intentional, physical and (or) mental effects, violates the constitutional rights to 
physical and mental integrity of the individual and directed at another person (s) against or in addition to its (their) will cause him (them) significant harm or creates a risk of such harm. From this definition are the following legal and factual features of the criminal offense of violence [1]: 1) wrongfulness of violence; 2) intentional violence; 3 ) physical and (or) mental impact; 4) the subject of the impact is physical and psychological basis of personality; 5) violence is directed against, or against the will and mind of the victim (the function of violence - suppression (destruction) or coercion); 6) socially harmful consequences in terms of substantial harm or danger of causing such.

Violent crimes account for a significant part of the normative content of the criminal law. However, they are not allocated by the legislator in a single chapter or section, as are its various structural elements. One indication of the distribution of crime, including violent, by chapters or sections of the Criminal Law of the Russian Federation is the object of a criminal assault. Practically in most criminal codes of foreign countries the crimes encroaching on the same generic object, as combined in the relevant chapters. This suggests that the structure of the Special Part of the Code does not have significant differences. However, the order in which certain crimes is different. There are three approaches, according to which the Structured special part of criminal law. Using a well-known scientific approach [2], we classify criminal codes of foreign countries. 1. The special part of the Criminal Code begins with the crimes against the person (CC Austrian Criminal Code of Argentina, the Criminal Code of the Republic of San Marino, of the Criminal Code). 2. The special part of the Criminal Code starts with state crimes (Criminal Code of Denmark, of the Criminal Code of the People's Republic, the Turkish Penal Code, the Criminal Code of Japan). 3. The special part of the Criminal Code begins with a crime against peace, humanity and war crimes. These crimes are put on top of the legislators - the former Soviet republics and a number of other European countries (of the Criminal Code, the Criminal Code of the Republic of Latvia, the Criminal Code of the Republic of Lithuania, the Polish Criminal Code, the Criminal Code of France, the Criminal Code of the Republic of Estonia). French legislator crimes against persons and crimes against humanity are not shared. In his opinion, infringing upon the interests of humanity, the offender infringes on the interests of the individual. Therefore, the second book of the French Criminal Code, entitled "Crimes and offenses against the person", begins with crimes against humanity. The position of the French legislator seems correct. If the Criminal Code of the Russian Federation in the first place in the Special Part will be delivered crimes against the peace and security of mankind, he will more accurately reflect the constitutional provisions on the priority of values in Russian society.

\section{Results}

Among the most dangerous violent crimes against the person, we should include murder. The definitions of this crime in the codes of most foreign countries are different, but the formulation is, as a rule, extremely simple.

In a number of criminal laws there are specified some objective evidence of murder. So, in the article 237 of the Criminal Code of Denmark (then it is abbreviated form CC) it is stated: «Any person, who kills another person, is guilty of murder». Its treatment in the art. 221-1 of the CC of France is most similar to the Russian definition of murder, namely: «the intentional infliction of death to another person (meurtre)». For the CC of France it is characterized the concept of premeditated murder (assassinat) which is understood as the deliberate murder, committed with in advance considered intention (Art. 221-3).

There aren't described the murder signs in the CC of People's Republic of China, CC of the Lithuania Republic, CC of Poland, CC of the San Marino Republic, CC of Japan and in some other criminal laws of the states. In the art. 199 of CC of Japan (murder) it is specified: «The one who killed the person, is punished by the death penalty or imprisonment with forced physical work without term or for the term of not lower than three years». § 1 of the Criminal Code of Poland contains in art. 148 approximately the same formulation of murder: «Who commits murder of the person, has a punishment by imprisonment for the term of not less than 8 years, or a punishment by imprisonment for term in 25 years or a punishment by lifelong imprisonment. The formulation of murder in the CC of Austria is a little differ: «Who kills the other person, is punished by imprisonment for a period of 10 till 20 years or lifelong imprisonment» (§ 75).

In the CC of Turkey there is emphasized deliberate nature of the act: «The person, who committed a premeditated murder, must be punished...»

Though some of the given definitions of murder don't contain the instruction on deliberate nature of this act, but the systematic analysis of norms allows drawing a conclusion that it is so. So, for example, in paragraph 80 of the CC of Austria there is a punishment for a manslaughter that allows drawing a conclusion, that in paragraph 75 it is about a premeditated murder.

In our opinion, the formulation of murder in the criminal code of Russian Federation is the most successful. There are specified in it objective (causing death, the other person) and subjective signs (intended) of this violent crime. Such definition allows to differentiate murder from manslaughter, murder - from the deliberate infliction of harm to the health, 
which entailed death of the victim, nonpunishable suicide on imprudence - from murder, emphasizes the cause and effect mechanism of these acts, classifying them on actions and inaction. In general all these signs create legislative bases for a formulation of a just punishment for the commission of this act.

The qualified types of murders are formulated differently. In the CC of Denmark there is no article in which the aggravating circumstances would be listed such as it is made in the criminal code of Russian Federation (Art. 63 of the criminal code of Russian Federation). And only at the description of signs of separate crimes there is an instruction on any aggravating circumstance. Probably, the law gives to the court the right to accept certain aggravating circumstances. For example, in the article 241 of the CC of Denmark it is about causing death to other person due to negligence. There is the next punishment for the specified crime: a penalty, the simple detention or imprisonment which isn't exceeding four months. If this crime is committed under the aggravating circumstances, the perpetrator is liable to imprisonment for any term not exceeding four years.

In the art. 221-4 of the Criminal Code of France there are listed circumstances aggravating of murder. There are called five such circumstances, and all of them are connected with a concrete figure of the victim (the minor who didn't reach 15 years; lawful or natural relative in the line of ascent, including adoptive parents; especially vulnerable persons owing to age, illness, pregnancy, etc.; the persons possessing the public power or being on public service, for ex. judges, notaries, prosecutors, etc.; witnesses, victims, civil claimants). In the art. 221-5 there is provided an encroachment on the human's life using substances that can cause death. This type of crime is called poisoning (empoison-nement). According to the CC of France the infliction of harm of life or to the persons' health, who didn't reach fifteen years, is considered in all types of violent crimes, as the punishment aggravating responsibility. Therefore it excludes consideration of a question of murdering of the newborn child by mother as a privileged kind of murder.

\section{Discussion}

In the Criminal Code of Japan there is provided by the special norm only one type of murder under the aggravating circumstances - a murder of the relative in the line of ascent with the murderer or his spouse (Art. 200 of the CC of Japan). And the sanction for this murder is stricter, than for murder without the aggravating circumstances. It includes the death penalty or termless imprisonment with forced physical work.

The considerable list of the circumstances strengthening responsibility for murder is provided by the art. 449 and 450 of the CC of Turkey. Among them there are: a murder of close relatives in a straight line and in the line of ascent, by poisoning, the former member of the Grand National Assembly of Turkey in connection with the performance of his duties as a Member of Parliament, with special cruelty or torture, and tortures for the victim, concerning two or more persons, by means of burning, drowning or a sinking, with the purpose to prepare or facilitate commission or to commit other crime, from revenge, concerning the government official in the performance of official duties or former government official in connection with the state position.

The Polish legislator allocates some types of the circumstances aggravating murder that pulls together these norms with the Russian norms on the qualified murder. So, in §2, art. 148 of the Criminal Code of Poland there are provided such circumstances, as special cruelty, a murder conjugation with hostage-taking, rape, robbery, use of firearms or explosives, murder of two or more persons, the existence of a former criminal record for murder.

In the Criminal Code of Austria there is no article which would describe types of murder under the aggravating circumstances. However the punishment for such murders is defined with paragraph 33 in which there are listed the aggravating circumstances at commission of any criminal actions.

The circumstances aggravating murder are specified in the criminal codes of the Baltic States. Their list is approximately the same, as well as in the Criminal code of the Russian Federation (then in abbreviated form the CC of the RF). However on the one circumstance specified in the p. 3 p. 2 art. 129 of the Criminal Code of the Lithuania Republic, it is necessary to stop. In this paragraph there is provided responsibility for the murder of the mother, the father or the child. It is represented to us that the same circumstance should be included and in the criminal code of Russian Federation. Social tension, growth of the marginal manifestations (alcoholism, drug addiction), spiritual dissoluteness, create the centers of high psychological voltage and discomfort in many families, permission of that quite often are the criminal dramas attracting death of close people. Unfortunately there are also frequent and cases of murder of close people from mercenary motives. Strengthening of responsibility for murder of parents, the spouse or children will serve in some way as a preventive measure, and also it will be promoted to the achievement of the objectives of punishment, which are written in the p.2 art. 43 of the criminal code of Russian Federation (Ivantsova \& Kalachyan, 2012).

Unlike the circumstances aggravating murder which aren't specified in a number of the CC of the foreign states, the circumstances softening murder in many of them are described more detail. 
Murder of the newborn child by mother is provided in the Criminal Codes of Austria, Azerbaijan Republic, Denmark, Latvia Republic, San Marino Republic, Uzbekistan Republic, Estonia Republic and in some other states. The similar norm is available in art. 106 of the criminal code of Russian Federation. In our law four equivalent conditions allow to qualify act according to the art. 106 of the criminal code of Russian Federation: murder during childbirth, right after childbirth, in the conditions of the psychoinjuring situation or in a condition of a mental disorder. In article 238 of the CC of Denmark there is no accurate allocation of these conditions, but their contents follows from the norm: «lf mother kills the child during or at once after the childbirth and if she acted, being in disaster, for fear about a shame or suffering from anguish owing to weakness, confusion or the panic caused by childbirth, she is liable to imprisonment for any term not exceeding four years». In the second part of the same article there is provided an exemption from punishment in the assassination of the crime, which didn't cause harm to the child.

More briefly this type of murder is described in the paragraph 79 of the CC of Austria: «Mother who kills the child in the course of childbirth or during that time when she is still under the influence of birth ..» In art. 453 of the CC of Turkey there is emphasized the purpose of commission of this sort of murders: «In case of commission by mother of murder of the newborn child for the purpose to save her honor...»

Especially it is necessary to stop on the murder cases at a request or the requirement of the victim, as in the criminal code of Russian Federation such murder isn't considered as made under the softening circumstances. The same approach is observed and from the authors of Azerbaijani, Belarusian, Turkish, French and some other criminal codes.

The CC of Denmark provides criminal liability for «euthanasia», that is a murder of the other person at the request of the last. «Euthanasias» are punishable according to the CC of Japan. In the CC of Poland this type of murder is a little differ. In exceptional cases the Polish legislator provided the possibility of release from punishment «for euthanasia». For reference of murder to this type it is necessary to reveal two legislative signs: 1) victim's request; 2) situation of compassion to the victim (Art. 150 of the CC of Poland).

Pronounced estimated character is inherent in similar norm in the $\mathrm{CC}$ of Austria, which recognizes cases under the murder on request of the victim, when such requirement from the victim is serious and persistent.

To the composition of a premeditated murder with the extenuating circumstances in foreign criminal laws, except above-named, belong the murder committed in the heat of passion (in terminology of the CC of Poland - «murder of the person under the influence of the strong excitement justified with circumstances»; in terminology of the CC of Austria «who takes all understandable strong spiritual experiences so, that kills another person»; in terminology of the CC of Argentina - «the one who killed another, being in a state strong and justified the circumstances of emotional excitement that took place»). It should be noted that in foreign criminal laws, except some states - the former republics of the Soviet Union (for example, art. 142 of the CC of the Belarus Republic, art. 123 of the CC of the Azerbaijan Republic, art. 122 of the CC of the Latvia Republics), there are no such privileged murders, as murder at excess of the measures necessary for detention of the person who committed a crime, murder at excess of limits of necessary defense or emergency.

Among the crimes against life on a legal regulation such act, as bringing to suicide or to attempt at suicide differs in some originality. According to the art. 110 of the criminal code of Russian Federation such act is a crime if it is made by threats, ill treatment or systematic humiliation of human dignity of the victim. In the criminal code of Russian Federation, as well as in the CC of the Baltic States, there are criminalized the violent ways of bringing to suicide.

A fundamentally different approach to bringing to suicide is fixed in the Polish Criminal Code. According to the art. 151 of the CC of Poland the one, who by arrangements or assistance brings the person to attempt at the life, must be punished with imprisonment from 3 months to 5 years. Besides, cases of the taken place suicide probably are regarded on the $\mathrm{CC}$ of Poland as murder, as in art. 151 of the $\mathrm{CC}$ of Poland it is only about bringing to attempt at suicide.

According to the article 241 of the CC of Denmark imprisonment for the term which isn't exceeding three years, is punished the help to other person in suicide commission which is carried out because of personal interest. If it was absent, in this case there is prescribed less strict punishment: penalty or simple detention (Art. 240).

The CC of Austria supplements the help in commission of suicide with such alternative sign as inducement of other person to suicide (paragraph 78).

According to the $\mathrm{CC}$ of France the instigation to suicide is punishable, if it is followed by suicide or attempt of suicide. The responsibility is enhanced, if the victim is a person, who didn't reach 15 years.

According to art. 454 of the CC of Turkey the person is responsible for it, if he convinces someone to commit suicide and assists him in this action, or if death occurs victim.

\section{Conclusion}

The carried-out analysis of criminal precepts of law about the crimes, made with application of violence shows a big 
variety in approaches to legislative reflection of socially dangerous violence. A number of the provisions of the foreign legislation, concerning the criminal liability for murder, would be necessary to direct on the improvement of norms in the criminal code of Russian Federation. So, it is necessary to include in number of the aggravating responsibility for murder signs, causing death to the parents, the spouse or the child.

For the structures of the violent crimes, encroaching on the human's life, there is provided a large number of the aggravating circumstances defining character and the amount of punishments in sanctions of norms in the criminal code of Russian Federation. The norms of the CC of France, of Turkey, and also of the states which left their structure of the USSR, are differ in similar specification of circumstances. It is represented that the desire of the legislator to establish the exhaustive list of the circumstances aggravating this or that type of crimes is the positive moment of law-making as in this case unreasonably wide judicial discretion is seriously excluded.

\section{References}

Ivantsova, N.V. (2015). Analysis of some short stories of Russian criminal law. Herald of Interregional Open Social Institute. №1., 46 49.

Ivantsova, N.V., Kuznetsova, N.F. (2014). On the classification of crimes in criminal law. Actual problems of jurisprudence in modern Russia: a collection of articles based on scientific and practical conference. Yoshkar -Ola: Interregional Open Social Institute. $2014,85$.

Ivantsova, N.V. Kalachyan, K.Y. (2012). Forced labor, alternative or independent type of punishment: the way of finding the right approach // the Russian justice. № 8., 58.

Ivantsova, N.V. (2004). Problems of reflection and evaluation of socially dangerous violence in the criminal law (theory and practice). Kazan: Publishing House of the University of Kazan, p. 53-86. 
